\title{
Real Property and Real Property Security: The Well-Being of the Law
}

\author{
John R. Hetland*
}

For all the great expansion of statutory law, indeed, in part because of $i t$, a judge has key responsibility for the well-being of the law. If he tends it badly or merely passively, it can develop weaknesses or disorders or, worse still, frightening powers, no matter how well put together it is. If he tends it well it will thrive, even if it is of clumsy structure. $\dagger$

$\mathbf{I}^{\mathrm{r}}$ IS REMARKABLE that one judge could contribute so much to so many different aspects of the law of real property and real property security. It is extraordinary that in so doing he could also reach such excellent results in the cases before him. It is almost unbelievable that he could so master the widely diverse problems involved as to write each opinion in terms of an overview toward possible reform of the entire substantive area suggested by each case. Yet Chief Justice Roger Traynor has accomplished all of this with such property problems as adverse possession, ${ }^{1}$ redemption, ${ }^{2}$ delivery of deeds, ${ }^{3}$ due-on-sale or call provisions, ${ }^{4}$ the land contract vendor's remedies, ${ }^{5}$ the antideficiency system, ${ }^{6}$ the masked

* B.S.I. 1952, LL.B. 1956, University of Minnesota. Professor of Law, University of California, Berkeley.

†Traynor, Better Days in Court for a New Day's Problems, 17 Vand. L. Rev. 109, 123 (1963).

1 See Sorenson v. Costa, 32 Cal. $2 \mathrm{~d} 453,196$ P.2d 900 (1948). This case is so wellwritten and covers so many of the problems arising out of adverse possession (possession founded upon mistake, tax payment on erroneous description, tacking of possession, etc.) that it is itself sufficient as a textbook on the whole subject.

2See Salsbery v. Ritter, 48 Cal. 2d 1, 306 P.2d 897 (1957). Here Justice Traynor resolved a patent ainbiguity in the redemption statutes, and by thorough explanation of the mechanics of Cahifornia's scramble redemption wrote what amounts to the best text in existence on the subject. His resolution of the ambiguity in a way which compels the debtor to pay all liens that have come into the redemption picture, seems to be the only permissible result under the statute and the best result from the standpoint of accomplishing the purpose of redemption. On the latter point, which is really a matter of philosophy or a question of what the legislature should have done, some may disagree. See Riesenfeld, Creditors Rights, in 6 SuRvey of CalIfornIA LAw 1953-54, at 151 (1955). None would disagree, however, that the opinion is sound as a matter of legislative interpretation.

${ }^{3}$ See Osborn v. Osborn, 42 Cal. 2d 358, 267 P.2d 333 (1954), for an excellent reexamination and realignment of the previously confusing delivery cases.

4 See Coast Bank v. Minderhout, 61 A.C. 307, 392 P.2d 265, 38 Cal. Rptr. 505 (1964), discussed in part III infra.

5 Barkis v. Scott, 34 Cal. 2d 116, 208 P.2d 367 (1949); Baffa v. Johnson, 35 Cal. 2d 36, 216 P.2d 13 (1950); Freedman v. The Rector, 37 Cal. 2d 16, 230 P.2d 629 (1951); Caplan v. Schroeder, 56 Cal. 2d 515, 364 P.2d 321, 15 Cal. Rptr. 145 (1961), discussed in part $I$ infra. Not discussed in the text, though, is the equally wise award of conse- 
security device, ${ }^{7}$ forcible entry and unlawful detainer, ${ }^{8}$ and several others depending on the scope of the "property" classification."

A catalogue of all of the opinions Chief Justice Traynor has written in the area of real property would itself be valuable and would demonstrate the remarkable breadth of his contribution to the field. To do so within the confines of a law review article, however, would preclude analysis of that which is equally as extraordinary as his substantive contribution, his unusual technique for reforming this traditionally inflexible field of the law.

This Article will concentrate upon three of the areas in which Traynor opinions have had an enormous impact, the land contract, the antideficiency system, and the masked security transaction. While it necessarily will consider the substance of each, the main purpose will be to illustrate the Traynor technique. An understanding of how he does what he does often enables one to read the signals present in his opinions and thereby predict what is likely to happen in related areas undergoing transition. Moreover, this may help to demonstrate what it is that has made him one of the nation's greatest jurists.

THE LAND CONTRACT VENDOR'S REMEDIES

The most dramatic example of change by the Traynor method is the land contract cases. In a series of three Traynor opinions ${ }^{10}$ the Cali-

quential out-of-pocket loss to the vendor in addition to his statutory measure of recovery under Civil Code \$ 3307. Compare Royer v. Carter, 37 Cal. 2d 544, 233 P.2d 539 (1951), with Caplan v. Schroeder, 56 Cal. 2d 515, 364 P.2d 321, 15 Cal. Rptr. 145 (1961). See also Allen v. Enomoto, 228 A.C.A. 916, 39 Cal. Rptr. 815 (1964).

6 Roseleaf v. Chierighino, 59 Cal. 2d 35, 378 P.2d 97, 27 Cal. Rptr. 873 i(1963); Bargioni v. Hill, 59 Cal. 2d 121, 378 P.2d 593, 28 Cal. Rptr. 321 (1963), discussed in part II infra.

7 Coast Bank v. Minderhout, 61 A.C. 307, 392 P.2d 265, 38 Cal. Rptr. 505 (1964), discussed in part III infra.

${ }^{8}$ Jordan v. Talbot, 55 Cal. 2d 597, 361 P.2d 20, 12 Cal. Rptr. 488 (1961). By holding the landlord's entry with a key during the tenant's absence to be a forcible entry, this case destroys the landlord's self-help remedy. Doubtless it will apply also to the land contract vendor and possibly to the chattel vendor. Initially it seemed unwise to force the parties to court in petty disputes. The increasing prevalence of disregard for the judicial process in other areas, however, has made it apparent that the court was correct in holding that even minor commercial problems whicb cannot be settled by negotiation niust not be resolved in any manner other than by the courts.

${ }^{9}$ Classifying that which is and is not within the scope of a real property and property security article is difficult. His recent opmion resolving the difficult mechanics hen stopnotice problem, for example, should perhaps be withm the scope of this subject. A-1 Doors Materials Co. v. Fresno Guar. Sav. \& Loan, 61 A.C. 790, 394 P.2d 829, 40 Cal. Rptr. 85 (1964).

10 Barkis v. Scott, 34 Cal. 2d 116, 208 P.2d 367 (1949); Baffa v. Johnson, 35 Cal. 2d 36, 216 P.2d 13 (1950); Freedman v. The Rector, 37 Cal. 2d 16, 230 P.2d 629 (1951). 
fornia Supreme Court discarded the whole spectrum of remedies that had belonged to the land contract vendor for better than half a century-remedies that were often unconscionable, frequently abused, and certainly in great need of revision. In a fourth opinion by Justice Traynor, ${ }^{11}$ the court refined its earlier reforms to avoid future apphications that could be broader than necessary to protect the vendee, and thereby could be unjust to the vendor.

Until 1949, the land contract vendor had a wide choice of remedies against both the willfully and the innocently defaulting vendee. While the vendor could obtain difference value damages or specific performance, it was his right to nonjudicial cancellation and forfeiture that impelled judicial re-examination of the land contract vendor's remedies. ${ }^{12}$ The harshest forfeitures were occasionally avoided by some variant of waiver, estoppel, or lack of tender, ${ }^{13}$ but loss of all of the payments he had made together with all improvements he had put on the land generally was the unhappy fate of the defaulting vendee. Whether or not the vendee's breach was willful remained, for the most part, immaterial, as did the other equitable question, whether or not the amount of his forfeiture exceeded the amount of the vendor's actual damage.

The whole forfeiture concept was wrong in its inception. The California Civil Code provided for relief from vendor imposed forfeitures, and required the courts to consider both the willfulness of the breach and the penal aspect of the forfeiture. ${ }^{14}$ The statutes, however, were overlooked in the first supreme court case to consider the subject, ${ }^{15}$ and; apparently to avoid imconsistency with the first opinion, were destructively limited by the courts in later cases in which their applicability could not be denied. ${ }^{16}$

11 Caplan v. Schroeder, 56 Cal. 2d 515, 364 P.2d 321, 15 Cal. Rptr. 145 (1961).

12 For a discussion of land contract vendor's remedies in California as they existed prior to the reform cases, see Comiment, 27 CaLIF. L. REv. 583 (1939). The entire land contract situation as it existed in 1960 was discussed in the California Law Review at that time. See Hetland, The California Land Contract, 48 CarIF. L. REv. 729 (1960). To avoid repetition, only what little is necessary to place the text in context is described here.

13 See, e.g., Boone v. Templeman, 158 Cal. 290, 110 Pac. 947 (1910); McDonald v. Kingsbury, 16 Cal. App. 244, 116 Pac. 380 (1911).

14 Civil Code $\$ 3275$ provides: "Whenever, by the terms of an obhgation, a party thereto incurs a forfeiture, by reason of his failure to comply with its provisions, he may be relieved therefrom, upon making full compensation to the other party, except in case of a grossly negligent, willful, or fraudulent breach of duty."

Civil Code $\$ 3369$ provides: "Neither specific nor preventive relief can be granted to enforce a penalty or forfeiture .... in any case ...."

15 Glock v. Howard \& Wilson Colony Co., 123 Cal. 1, 55 Pac. 713 (1898).

10 See, e.g., Collins v. Eksoozian, 61 Cal. App. 184, 214 Pac. 670 (1923); Ebbert v. Mercantile Trust Co., 213 Cal. 496, 2 P.2d 776 (1931); Henck v. Lake Hemet Water Co., 9 Cal. 2d 136, 69 P.2d 849 (1937). 
'Barkis v. Scott ${ }^{\mathbf{1 7}}$ was the first in a series of Traynor opinions reforming the vendor's remedies. The court simply applied one of the Civil Code antiforfeiture provisions, section 3275 , without its inappropriate judicial amendments. While it made only a shight modification, this first of the reform series would have been an ideal case factually to accomplish the entire change of remedies that concluded two years later in Freedman $v$. The Rector. ${ }^{18}$ Barkis involved a long term installment contract, an uncommonly harsh forfeiture, and a trial court finding that the vendee's default was willful. This was a far better factual setting in which to reach what turned out to be the court's ultimate conclusion-that a willfully defaulting vendee has an unqualified equity of redemption - than was ever again presented to the court. Had the court so held in Barkis, it would have destroyed the entire vendor's arsenal in a single unprecedented holding. But to convert without warning the common land contract into a totally different, and from the vendor's standpoint, totally unacceptable, security device would have been terribly unsetthing. Retroactive inplementation of such a change before the Bar could adjust and advise concerning it, doubtless would have had substantial and often unfair effects on executory land transactions. Justice Traynor, writing for the majority, took only the first step, but in so doing signaled the changes to come.

Barkis had within it several important signs, the most significant of which was the court's treatment of the facts. The trial court had found, apparently on substantial evidence, that the vendee's breach had been willful. In order to bring the vendee under Civil Code section 3275, the court had to redetermine the factual issue and hold that as a matter of law the vendee's breach was neither willful nor grossly negligent within the meaning of that statute. This kind of factual redetermination in the face of evidence clearly sufficient to support the finding is so extraordinary that of itself it indicates that the court is concerned about something other than its seeming disagreement with the trial court's resolution of the facts.

The key, of course, was that the holding in Barkis was not a factual redetermination at all but a tentative redefinition of the terms of Civil Code section 3275. That section purports to provide for relief to the vendee only if his breach is not "grossly negligent" or "willful." Yet, if the vendee's breach in Barkis was not one or the other very few breaches ever would be. The holding, in other words, really related to a willfully breaching vendee, and it gave him what amounted to the same equity of redemption he would have had had he given as security the economically similar deed of trust or mortgage. By masking it's decision behind a

1837 Cal. 2d 16, 230 P.2d 629 (1951). 
factual redetermination, the court was giving notice of these expanded rights for defaulting vendees without actually committing itself to them. By this method Justice Traynor warned of the change, and yet left room for the court to retreat by dismissing Barkis as a simple sufficiency of the evidence problem if later comment and argument were to prove the reform ill-advised. In either event, the unwarranted entanglements to Civil Code section 3275 would have been excised, itself an excellent reform, and the defendant vendee would have been reheved of a harsh forfeiture with little, if any, damage to plaintiff vendor.

The law review comments were laudatory, ${ }^{18}$ the arguments of counsel in favor of going forward with the reform apparently were more convincing than those against it, and the process of reform continued with another even clearer warning.

The plaimtiff in the next case in the series, Baffa v. Johnson, ${ }^{20}$ was unquestionably a willfully defaulting vendee. This time, however, there was no reappraisal of the facts, and there was no attempt to fit this vendee within what could have been the new Barkis definition of "willfulness." Here the willfully breaching vendee sued for return of his earnest money. The defendant seller could have recovered only the statutory measure of damages had the seller been the plaintiff; therefore, argued Baffa, the seller's retention of anything in excess of that amount would be a forfeiture. Baffa failed to prove the difference between the value of the property at the time of the contract and at the time of the breach, and thereby failed to show that the seller in fact had retained more than his statutory measure. ${ }^{21}$ Although denying Baffa any recovery for this reason, Justice Traynor spelled out Baffa's argument and implied that when the issue arose with a plaintiff who had proved the ingredients of a penalty, i.e., payments in excess of difference value damages, the court would hold that the willfully defaulting vendee is entitled to restitutionary relief. Here then was the second warning, stated in a way that came closer to committing the court than had the Barkis approach, and stated in a way that was too clear for anyone to miss.

A plaintiff who fulfilled the requirements appeared in 1951. His default was willful, and the ainount he was to forfeit was clearly in excess of the

10 Included in this list should be those which urged the reform even before it commenced. See, e.g., Ballantine, Forfeiture for Breach of Contract, 5 Mrvv. L. Rev. 329, 341 (1921); Vanneman, Strict Foreclosures in Land Contracts, 14 MnNo. L. REv. 342 (1930); 18 Caxif. L. Rev. 681 (1930); 27 Calif. L. Rev. 583 (1934); 37 Calif. L. Rev. 704 (1949); 23 So. CaI. L. Rev. 111 (1949); 2 Stan. L. Rev. 235 (1949).

2035 Cal. 2d 36, 216 P.2d 13 (1950).

21 CAI. CTv. CODE \& 3307: "The detriment caused by the breach of an agreement to purchase an estate in real property, is deemed to be the excess, if any, of the amount which would have been due to the seller, under the contract, over the value of the property to him." 
vendor's damages. Moreover, the bar had been given adequate warning. In the third Traynor opinion of the series, Freedman v. The Rector, ${ }^{22}$ the court clearly held what had been presaged by Barkis: A willfully defaulting vendee is entitled to restitution of all benefits conferred in excess of the vendor's actual difference value damage. ${ }^{23}$

It is clear from Barkis that the innocently defaulting vendee is entitled to restitution or to reinstatement, whichever he prefers, under Civil Code section 3275. It is clear from Baffa and Freedman that the willfully defaulting vendee is entitled to restitution notwithstanding that section 3275 does not purport to protect him. Technically unresolved, however, is the question of whether or not the willfully defaulting vendee also can refuse restitution and instead reinstate the contract so that he has the same equity of redemption as a mortgagor or trustor. The Traynor warnings with respect to this question are so clear, however, that it has to be considered resolved in the vendee's favor. The court gave the willfully defaulting vendee in Freedman restitutionary relief instead of specific performance only because his repudiation had resulted in the defendant's sale of the property to a third person. Moreover, Justice Traynor said in the first of the series, Barkis, that reinstatement is preferable to restitution because of the difficulties of proof inherent in the latter, meaning that neither specific proof of a penalty or a showing of non-willfullness is a prerequisite to equitable rehef. Undoubtedly, the Ninth Circuit read the Traynor signals correctly when it held that California law grants the alternatives of restitution or reinstatement to the willfully, as well as to the innocently, defaulting vendee. ${ }^{24}$

It seems evident that Chief Justice Traynor's purpose in changing the law gradually through a series of cases without totally committing the court initially is not only to afford the bench, the bar, and the business community an opportunity to adjust to what is coming, but also is to give the bar and the legal commentators an opportunity to discuss and demonstrate both the strengths and the weaknesses of the suggested changes. The legal commentators, and perhaps the bar, let him down in the land contract series.

2237 Cal. 2d 16, 230 P.2d 629 (1951).

23 CAI. CIv. Code $\$ 3307$. When additional selling expenses to the vendor are the natural consequence of the vendee's breach, they may be recovered in addition to those provided for in § 3307. Royer v. Carter, 37 Cal. 2d 544, 233 P.2d 539 (1951); Caplan v. Schroeder, 56 Cal. 2d 515, 364 P.2d 321, 15 Cal. Rptr. 145 (1961).

24 Ward v. Union Bond \& Trust Co., 243 F.2d 476 (9th Cir. 1957). While good arguments can be made that Ward is not California law, see, e.g., Comment, 10 Star. L. REv. 355 (1958), these arguments go mainly to Ward's effect on the marketing contractto which Ward probably is inapplieable. Ward seems clearly to be the Cahfornia position with respect to the installment contract. See Hetland, The California Land Contract, 48 CArTF. L. REv. 729, 762-66 (1960). 
While there was considerable comment in the law reviews, all concentrated upon the overwhelming inequity likely to result from strict apphication of the old forfeiture remedies to the installment contract vendee. $^{25}$ None discussed the possible desirability of liquidated damages or even of earnest money under the marketing land contract, the contract used as a basic buy-sell document rather than as a security device. None for that matter discussed the differences between the two even though the security device function of the one leads to considerable differences in the measure of damages, the applicability of the antideficiency legislation, the risk of loss, and, probably, the desirability of substituted performance, hquidated damages, or earnest money. ${ }^{26}$

Had there been sufficient concentration upon the differences, it is possible that the court would have refused to hear Freedman, a marketing case, and instead would have awaited an installment case similar to Barkis to complete the reform. Justice Traynor recognized the distinction as his opinion in Freedman makes evident. But the profession manifested so little concern about it that doubtless it seemed to him less important to await an installment case than to complete the reform, as urged by the writers. Refinement could come later. Actually, by writing an opinion that was appropriate mainly to the installment contract in the face of Freedman's marketing contract facts, Justice Traynor even as he concluded the reform was forecasting the refinement to come.

The holding in Freedman, by its facts, clearly applied to the marketing contract, and this application virtually eliminated the use of liquidated damages in such contracts. Doubtless this was of concern to Justice Traynor when he cast the Freedman opinion in installment langnage. The apparent loss of liquidated damages as a remedy for the marketing contract vendor proved to be more of a trap for the unsophisticated seller than a beneficial reform for the uninformed buyer. In some cases mechanical relief to the buyer was as unjust to the seller as the pre-Freedman rules had been to the buyer.

Caplan v. Schroeder ${ }^{27}$ reached the supreme court in 1961 with facts that so highlighted the necessity for the vendor's retention of the deposit that both the trial court and the district court of appeal ${ }^{28}$ had strained to avoid the restitution that Freedman compelled. Although Caplan made it evident that the application of Freedman to the wrong

25 See authorities cited at note 19 supra. The commentaries continued for years thereafter even though the issue was settled. See, e.g., 7 U.C.L.A. L. REv. 83 (1960).

26 For a complete discussion of the differences between the marketing and installment contract and of the resultant remedial differences, see Hetland, The California Land Contract, 48 CAIIF. L. Rev. 729 (1960).

2756 Cal. 2d 515, 364 P.2d 321, 15 Cal. Rptr. 145 (1961).

28 For the District Court of Appeal's opimion, see 10 Cal. Rptr. 399 (1961). 
kind of case was unjust, the earlier Barkis, Baffa, and Freedman series made it equally evident that the reforms of those cases were too important to lose. Faced with this dilemma, Justice Traynor applied Freedman but still used the Caplan case as the vehicle to point out to the bar how to avoid the Freedman result where the parties truly intend a hquidation of damages. He refined Freedman without really compromising it.

If one were to read Caplan without having Freedman in mind, the Caplan decision would seein unnecessarily destructive of the earnest money concept..$^{29}$ This concept, however, already had been destroyed, and what was needed was not its reincarnation but a substitute which would be fair to both vendor and vendee. Liquidated dainages is an ideal coinpromise, avoiding as it does unintentional forfeitures, yet allowing the parties a litigation avoidance device. ${ }^{30}$ Caplan pointed out how an enforceable clause could be drafted for a marketing contract.

The land contract series starting with the Barkis case, continuing through Freedman and concluding, for the time being at least, with Caplan, show a great deal about Chief Justice Traynor and the Traynor method. He warned, then reformed, then refined. Writing for the majority, he totally discarded and replaced that which had existed for decades, but he made these profound changes in a moderate manner. The changes were not disruptive as they would have been had they been suddenly thrust upon the bar and business community before both were able to adjust and develop more equitable substitutes. Nor were they radical, using the unfavorable connotation of the word, because the reform left open its own scope to be refined where experience proved that a literal application would go too far. These cases

${ }^{29}$ See, e.g., Corban, Contracts \& 1132 n.79.5 (1964). Professor Corbin also finds Caplan destructive of the concept of separate consideration. He analogizes Caplan to the "bonus baby" cases, and argues that just as the athlete who signs a single contract for both bonus and salary has an enforceable right to both, so too Schroeder should have a right to the consideration paid to him for signing the land contract as well as to the consideration to be paid him for the land. The two would be truly analogous only if the bonus baby's bonus were to be later deducted from his salary. The further difficulty with Corbin's argument is that it presupposes that an athlete is real property. The land contract in California is' so infected with problems of the seeured transaction, that one cannot fully analogize a land case to any other kind of contract. The principles simply are not interchangeable. The marketing contract, however, probably should be treated as a contract and not as a mortgage, and the law is beginning to change in that direction. By refining Freedman, Caplan is a nuajor step in precisely the direction Professor Corbin urges it to go.

$30 \mathrm{CAL}$. Crv. CoDE $\S 1671$ provides: "The parties to a contract may agree therein upon an amount which shall be presuned to be the amount of damage sustained by a breach thereof, when, from the nature of the case, it would be impracticable or extrenrely difficult to fix the actual damage." 
alone would mark Chief Justice Traynor as a great jurist, and would of themselves be a magnificent contribution to California real property law. Yet they represent only a small part of his contribution.

\section{II}

\section{ANTIDEFICIENCY IEGISLATION}

In two recent opimons by Justice Traynor, Roseleaf v. Chierighino ${ }^{31}$ and Bargioni v. Hill, ${ }^{32}$ one may find the answer to virtually all of the legal problems created by the several Califorma statutes ${ }^{33}$ which reduce or eliminate the debtor's personal hability to his secured creditor. That two opinions could do so is remarkable; the statutes look as if they were drafted as a challenge to the judiciary's ability to determine what the legislature sought to accomplish. Yet, these two Traynor opinions not only directly resolved some of the most difficult antideficiency questions, but also reexamined all of the many purposes that have been attributed to the legislature in its enactment of the antideficiency legislation by the courts and the writers. Justice Traynor discarded most of these purposes, and settled on certain ones that establish a frame of reference for the resolution of remaining deficiency questions. ${ }^{34}$ Moreover, as was true with the early land contract cases, he has signaled some important changes without actually committing the court to them, thereby affording the profession the opportunity to consider whether or not the proposed course is sound, and if it is, to adjust to the change.

The best example of a Traynor change signal in the deficiency area is the analytical-though not actual-overruling of Brown v. Jensen $n^{35}$ by the Roseleaf case. This was discussed in the California Law Review

3159 Cal. 2d 35, 378 P.2d 97, 27 Cal. Rptr. 873 (1963).

8259 Cal. 2d 121, 378 P.2d 593, 28 Cal. Rptr. 321 (1963).

83 CaL. Code Crv. Proc. \$\$ 580a, 580b, 580d, 726.

84 The best example of the use of the framework established by Justice Traynor in Roseleaf is the resolution of the guarantor problem. It is reasonable to conclude that the guarantor has neither antideficiency protection nor recourse against the principal obligor. The appellate courts that have considered this problem since Roseleaf have come to this conclusion. See Heckes v. Sapp, 229 A.C.A. 644, 40 Cal. Rptr. 485 (1964); cf. Valinda Builders, Inc. v. Bissner, 230 A.C.A. 112, 40 Cal. Rptr. 735 (1964) (Same result impled, but the "guarantors"-those signing the contract as individuals-were held to be principals and thus under the shelter of section 580b of the Code of Civil Procedure, although title had been taken by their subsequently formed, wholly owned corporation. Given this factual determination, the case is consistent with Heckes v. Sapp, supra, and such earlier cases as Riddle v. Lushing, 203 Cal. App. 2d 831, 21 Cal. Rptr. 902 (1962)). How the Roseleaf leads to this conclusion, why the result seems better than the alternatives, and how other deficiency problems can be resolved within the same Roseleaf framework were discussed in the California Law Review shortly after the opinion was handed down, and will not be repeated herein. See, Hetland, Deficiency Judgment Limitations in California-A Neve Judicial Approach, 51 CaLIF. L. Rev. 1 (1963).

3541 Cal. 2d 193, 259 P.2d 425 (1953). 
shortly after the opinion and will not be repeated here. ${ }^{36}$ Not discussed at that time, however, were whether or not the change seemed desirable and the subsequent events that make the actual overruling of Brown seem even more hikely than it did at the time of Roseleaf.

Brown v. Jensen held that section 580b of the Code of Civil Procedure prevented a junior purchase money lender from recovering a personal judgment against the borrower even though his security had been exhausted by senior sale and the junior had had no recourse to the security. Roseleaf stripped Brown of all of the reasons that supported it, but the question that Justice Traynor left open for the bar and writers to consider was whether or not Brown's result is sufficiently valuable to justify its retention as a single exception to an otherwise consistent pattern of interpretation of the deficiency provisions. It seems even less so now than at the time Roseleaf was decided.

The vast majority of junior purchase money lenders probably are individual sellers. Institutional lenders rarely can, or will, take a junior encumbrance. ${ }^{37}$ Furthermore, the 1963 amendment to the purchase money section, ${ }^{38}$ allowing third party lenders to recover against commercial, as opposed to residential purchasers, even more heavily thrusts the burden of Brown v. Jensen on the individual seller. Now he is the only lender who remains barred against all buyers including the most likely deficiency judgment candidate, the property developer. To decide, therefore, whether or not a sold-out junior should be able to recover a judgment on the note after a senior has taken all of the security, one has to decide who the buyer and seller are likely to be and then compare their relative equities.

If the junior is the individual residential seller taking a second for the top part of the purchase price, there is little reason to protect the buyer at his expense. Neither one has the property, the senior hen holder having taken it, and both are likely to be in about the sanie economic condition. Moreover, the seller is likely to have bought another house and be unable to make the additional investment required to re-

36 Hetland, note 34 supra at 7-12.

37 Moreover, most of the cases concern sellers rather than non-regulated commercial lenders, suggesting that most of the credit in question comes from the seller, and that the seller rarely discounts his second paper.

38 The following italicized language was added to the final paragraph of the Code of Civil Procedure $\S 580 \mathrm{~b}$ in 1963: "No deficiency judgment shall lie in any event after any sale of real property for failure of the purchaser to complete his contract of sale, or under a deed of trust, or mortgage, given to the vendor to secure payment of the balance of the purchase price of real property, or under a deed of trust, or mortgage, on a dwelling for not more than four families given to a lender to secure repayment of a loan which was in fact used to pay all or part of the purchase price of such dwelling occupied, entirely or in part, by the purchaser." 
instate the senior lien. It is hard to find a good argument in favor of requiring him to do so upon pain of losing his entire claim, ${ }^{39}$ yet under the Brown result remstatement is the junior's only alternative.

Perliaps the greatest inequity in Brown v. Jensen lies in its application to the junior who became so by subordinating his purchase money hen to the buyer's construction loan. Often the subordinated seller will be a nonprofessional in the real property business, a rancher or farmer, for example, and the buyer will be a real estate promoter or developer. Since the construction loan typically is several times larger than the seller's land loan, the subordinated seller rarely has any hope of reinstating the construction loan in the event of the developer's default. If doing so is a prerequisite to his protection, as it is under Brown v. Jensen, he is without remedy. There is nothing in section $580 \mathrm{~b}$ that expressly precludes the junior froin recovering a judgment against the developer for the amount owing after the construction lender takes the security; only Brown $v$. Jensen's strained construction of $580 \mathrm{~b}$ prevents it.

Brown v. Jensen allows the developer to treat the subordinated seller's note more or less as an option he can walk away from at any time without fear of liability. But Justice Traynor's Roseleaf opimion has given notice that this situation is not likely to continue. As the developer becomes aware of his potential personal liability to the subordinated seller he is less likely to pay more, even though only on paper, than the land is reasonably worth. This may tend toward the stabilization of land values, suggested by Justice Traynor in Roseleaf as one of the goals of the antideficiency system. After all, the developer might actually have to pay his note if the Roseleaf analysis supersedes that of Brown so that a secured purchase money note may becoine a legitimate, payable part of the price.

For a long time, the courts protected the subordinated seller by requiring subordination clauses to be drawn with a degree of precision virtually necessitating knowledge of the terms of the construction loan at the time of the sale contract. ${ }^{40}$ Often such information was not available at the time, and therefore strict construction, rather than being equitable protection for the seller, could be inequitable to the buyer and

39 With respect to the inequity of forcing the junior to make an additional investment to protect himself, Justice Traynor said in Roseleaf: "Equitable considerations favor placing the burden on the debtor, not only because it is his default that provokes the senior sale, but also because he has the benefit of his bargain with the junior lienor who, unlike the selling senior, might otherwise end up with nothing." 59 Cal. $2 \mathrm{~d} 35,41$, 378 P.2d 97, 100, 27 Cal. Rptr. 873, 876 (1963).

${ }^{40}$ See, e.g. Kessler v. Sapp, 169 Cal. App. 2d 818, 338 P.2d 34 (1959); Roven v. Miller, 168 Cal. App. 2d 391, 335 P.2d 1035 (1959); Gould v. Callan, 127 Cal. App. 2d 1,273 P.2d 93 (1954). 
construction lender. Recently, the cases have been loosening the requirements for an enforceable subordination agreement so that most clauses which cover all that reasonably can be expected to be known at the time of the executory contract will be enforced. ${ }^{11}$ This means that the seller's protection has to be something other than the early solutions of avoiding the contract, ${ }^{42}$ reestablishing his former priority, or awarding him damages against the construction lender who failed to achieve total priority. ${ }^{43}$

The obvious answer is to allow the subordinated seller to recover on the note after the security is exhausted by a senior sale in which he did not share. This result is permissible under section $580 \mathrm{~b}$, is assumed under Code of Civil Procedure section 726, ${ }^{44}$ is suggested in Roseleaf, ${ }^{45}$ and yet is precluded for the time being by Brown v. Jensen. In undermining Brown, by reconsidering and discarding its reasons as part of his analytically contrary Roseleaf opmion, Justice Traynor probably had many of these things in mind. Since Brown v. Jensen is at the heart of the subordination difficulties, it makes more sense to get rid of Brown v. Jensen than to encourage the piecemeal, often internally inconsistent, subordination solutions that the lower appellate courts have been forced into for the last decade.

It is difficult to see what could justify retaining Brown v. Jensen to distort what has become an otherwise consistent pattern of antideficiency interpretation. The likelihood is that it was overruled in Roseleaf, but pursuant to the Traynor approach, overruled only by implication so that it reverts really to an open question, awaiting thorough, direct argument by counsel. ${ }^{48}$

Another nagging deficiency question was put to rest in Bargioni v. Hill, which followed Roseleaf by a few weeks. The opinion incorporated the reasoning of Roseleaf by reference in concluding that third party

41 See Stockwell v. Lindeman, 229 A.C.A. 867, 40 Cal. Rptr. 555 (1964); Burrow v. Timmsen, 223 Cal. App. 2d 283, 35 Cal. Rptr. 668 (1963); Comment, 52 CALIF. L. Rev. 157, 160 (1963); cf. Magna Development Co. v. Reed. 228 A.C.A. 259, 39 Cal. Rptr. 284 (1964). But see Conley v. Fate, 227 A.C.A. 456, 38 Cal. Rptr. 680 (1964).

42 See cases cited in note 40 supra.

43 See Collins v. Home Sav. \& Loan Ass'n, 205 Cal. App. 2d 86, 22 Cal. Rptr. 817 (1962).

44 The one form of action statute has never been a bar after the security is exhausted by semior sale. Merced Sec. Sav. Bank v. Casaccia, 103 Cal. 641, 37 Pac. 648 (1894); Security First Nat. Bank v. Chapman, 31 Cal. App. 2d 182, 87 P.2d 724 (1939); Ferry v. Fisk, 54 Cal. App. 763, 202 Pac. 964 (1921).

45 For an analysis of the parity between Roseleaf's 580a reasoming and result, and the $580 \mathrm{~b}$ issue which was before the court in Brown, see Hetland, note 34 supra at 7-12.

46 Bargioni v. Hill assumed the applicability of Brown v. Jensen without mentioning the case. But it was decided only three weeks after Roseleaf, was argued before Roseleaf, and was thus not the proper vehicle for the overruling. 
money, money lent by someone other than the seller, is purchase money for purposes of section 580b's purchase money deficiency prohibition. Inasmuch as the statute appeared to be aimed at debtor protection and contained within it no exemption for third party lenders, and inasmuch as no rational purpose for the statute would suggest that third party lenders should have been exempt, the holding seems by no means remarkable. But in the thirty odd years between the statute's enactment and the Bargioni decision, no case had clarified the point and other state courts had reached opposite conclusions under somewhat similar provisions. ${ }^{47}$ Moreover, a few writers had assumed, ${ }^{48}$ and the clearest dicta in the lower California appellate courts suggested, the opposite result. ${ }^{49}$ Recognizing that the reasons given for the third party exemption were analytically unsound and often untrue, ${ }^{50}$ Justice Traynor's opinion simply exposed the fallacy upon which the opposite result was based and held that the statute applied in the broad form in which it was written, without third party exemption.

Shortly after Bargioni, and presumably in response to it, the legislature amended section $580 \mathrm{~b}$ to give third party purchase money lenders a right to a deficiency judgment in some situations. The scope of the change, however, makes it apparent that it is an affirmation of the Traynor views expressed in Bargioni, not a repudiation of them. Carrying forward Justice Traynor's description of the class to be benefited, the residential purchaser, ${ }^{51}$ the legislature left him the broad protection that the Bargioni case established with respect to vendor and third party creditor alike. It withdrew the protection only from the commercial or non-residential purchaser. Since Justice Traynor concluded that the statute must have been intended to protect the residential purchaser in the first place,

47 See, e.g., Ladd \& Tilton Bank v. Mitchell, 93 Ore. 668, 184 Pac. 282 (1919).

48 See, e.g., Currie \& Lieberman, Purchase-Money Mortgages and State Lines: A Study in Conflict-of-Laws Method, 1960 Duke L.J. 1; Comment, 15 Stan. L. Rev. 121, 123 (1962). Professor Riesenfeld, however, correctly predicted the California result several years before it was decided. Riesenfeld, California Legislation Curbing Deficiency Judgments, 48 CALIF. L. REv. 705, 713-16 (1960).

49 Peterson v. Wilson, 88 Cal. App. 2d 617, 199 P.2d 757 (1948).

50 For example, Peterson v. Wilson, supra note 49 , relying upon Ladd \& Tilton Bank v. Mitchell, 93 Ore. 668, 184 Pac. 282 (1919), suggested that unless third party lenders were exempted, home buyers might not be able to obtain loans, thus injuring rather than benefiting the class to be protected. Another common argument is that $\$ 580 \mathrm{~b}$ had the effect of protecting the buyer by forcing the vendor to sell the property at a price near its fair market value. See Comment, 15 STAN. L. REv. 121 (1962). Both seem quite unsound. See Hetland, supra note 34, at 15-24.

61 The residential purchaser is defined by the amendment to be one who purchases and occupies, entirely or in part, a dwelling for not more than four families. Whether or not a purchaser has occupied a dwelling within the meaning of the statute is probably a fact question to be determined by reference to duration of occupancy and the purchaser's evident motivation to buy a home or to carry on an investment program protected by $\S 580 \mathrm{~b}$. 
withdrawal of the protection from the commercial purchaser is completely consistent with his Roseleaf and Bargioni opinions. Equally consistent and even better legislation would have been to withdraw the protection from the commercial purchaser entirely and to allow even the vendor to recover from him. Surprisingly, this is what Witkin's Summary of California $\mathrm{Laze}^{52}$ said the amendment did, and most would share with Mr. Witkin the wish that it had. But the amendment clearly is not that broad.

For some reason, the two written comments to date on the 1963 amendment to section $580 \mathrm{~b}$ are inconsistent with each other and are inconsistent with what the statute says. One errs in describing the class of lenders barred, ${ }^{53}$ the other in describing the class of purchasers protected..$^{54}$ Both overlooked that the amendment affected each class only in part so that it actually protects residential purchasers from all lenders and commercial purchasers from the seller only. In other words, it narrowed the statutory prohibition only insofar as third party lenders may now recover deficiencies from non-residential purchasers.

Perhaps the amendment can be explained in terms of lobbying by institutional lenders coupled with the fact that sellers, as a class, have no lobby. The increasing prevalence, however, of purchase and sale by institutional leaders, ${ }^{55}$ presumably to avoid hinitations on the percentage they may loan, may lead the same institutional lenders, who thereby become vendors barred by the commercial borrower's deficiency protection, to advocate an amendment withdrawing the protection from commercial borrowers regardless of the identity of the lender. It would be a good change; it would make Witkin correct, albeit somewhat premature; and it would be completely consistent with the philosophy underlying Justice Traynor's resolution of the purchase inoney problems in Roseleaf and Bargioni.

Considering only these three aspects of Clief Justice Traynor's latest antideficiency opinions, it is evident that here, as in the other property areas, his opinions have had an enormous impact. Here, as in the other areas, he seems to be in the process of changing that which is inequitable, impractical, or obsolete. Here, as in the other areas, he is doing so in the

621 Witkm, Sunmary of CaLIFornia LaW $\$ \S 68,70 B$ (Supp. 1964).

53 Ibid. Witkin states "The 1963 Legislature limited the scope of the statute to sale of dwellings. ..." (Id. § 68) "The broad coverage of all purcliase money mortgages by C.C.P. $580 \mathrm{~b}$ was abandoned in 1963 . The section now refers to a mortgage or deed of trust 'on a dwelling for not more than four families.'" (Id. § 70b).

54 "The amendment clearly limits the section to instruments given to the vendor, that is, the section is confined to what has been traditionally regarded as a purchase money instrument, two party paper between vendor and vendee." 38 Car. State B.J. 671 (1963).

65 Apparently this is becoming an increasingly common practice. For a possible example of one variation of it, see Slusett, Inc. v. Home Sav. \& Loan Ass'n, 231 A.C.A. 181, 41 Cal. Rptr. 622 (1964). 
cautious, thoughtful manner that both assures the justice of his result in each case and assures that each case is part of a framework in which to carry forward the changes that are required.

\section{III}

\section{THE MASKED SECURITY DEVICE AND THE DUE-ON-SALE CLAUSE}

Chief Justice Traynor's most recent contribution to real property security law parallels in importance his land contract reforms and his antideficiency reanalysis. Perhaps because it is a short opinion, perhaps because the procedural context of the case hides the enormously difficult problems involved, or perhaps simply because insufficient time has passed for its real impact to be felt, Coast Bank v. Minderhout ${ }^{56}$ seems to have been largely overlooked by the legal writers and to have been vastly underestimated by the practicing real property bar.

On a quick reading, one could conclude that Coast Bank is a fairly common procedural holding to the effect that a particular document which was alleged by the plaintiff to be a hen was in fact a hien for purposes of the case because the defendant so admitted by demurring and failing to answer. Those ignoring the substance of the decision on this basis may lack an appreciation of the Traynor approach. To dismiss the important contribution of the Coast Bank decision as pure dicta surrounding a procedural holding is akin to having dismissed Baffa v. Johnson, ${ }^{57}$ the interim land contract case, for a similar reason. Yet, the substance of Baffa reappeared within a year as the holding of Freedman $v$. The Rector ${ }^{58}$ in precisely the way Justice Traynor had warned that it would. Even more than Baffa, Coast Bank is either a landmark decision or a very compelling sentinel.

Coast Bank dealt with an agreement by a borrower not to encumber or transfer certain real property. Although executed by the borrower along with a note covering some small loans and some contemplated future advances, the agreement failed to state whether or not it was a lien on the property to secure the indebtedness. The agreement, which is similar to that used by many California banks, provided that the borrower would neither sell nor encumber certain described real property until such time as he had repaid all present and future advances. It provided also for acceleration of all indebtedness in the event of default in payment or in the event of breach of the property agreement. This latter provision is like the call or due-on-sale provision of a mortgage or trust deed because the inost hkely breach of the agreement, as distinguished from a default

6061 A.C. 307,392 P.2d 265, 38 Cal. Rptr. 505 (1964).

8735 Cal. 2d 36, 216 P.2d 13 (1950), discussed in part I supra.

8837 Cal. 2d 16, 230 P.2d 629 (1951), discussed in part I supra. 
on the note, would be the borrower's sale or encumbrance. Finally, it afforded the bank the right to record the agreement at such time as the bank might choose. The substantive issue in Coast Bank was whether or not this created a security interest in the property.

Fifty years ago when creditors were experimenting with masked security devices intended to obviate the necessity for foreclosing the debtor's equity of redemption, the answer to this one would have been easy. It would have been a mortgage. ${ }^{59}$ But after the effect of the absolute deed with separate oral or written defeasance, the sale with an option to repurchase, and the various escrow and holding agreements was resolved, litigation on the problem virtually disappeared for several decades..$^{00}$ When the hidden security cases began reappearing in the appellate courts a few years ago, they usually concerned the factual notice issues arising out of homemade security devices ${ }^{61}$ and simply did not lend themselves to consideration of the effect upon the masked security problem. of legislative changes during the last fifty years.

Coast Bank, lowever, involved neither notice problems nor homemade mortgages, and by the time it reached the supreme court, a great deal had happened to the security system. No longer was the question confined to the easy factual issues of attempted avoidance of an equity of redemption; instead it now inported all of the deficiency, acceleration, reinstatement, form of action, redemption, and recordation changes of the last fifty years. In other words, a holding that a document which purports on its face not to be a hen is in fact a lien means far more today in terms of the debtor's remedies than it did when such a decision simply meant that the debtor had the right to redeem or that the creditor had the reciprocal obligation to foreclose. ${ }^{22}$ And to place this complex problem in the context of an agreement used by a substantial number of institutional lenders and affecting an enormous amount of money certainly makes any decision construing it both very difficult and very important. Such, was Coast Bank.

Justice Traynor, writing for the unanimous court, held the agree-

69 See, e.g., Bradbury v. Davenport, 120 Cal. 152, 52 Pac. 301 (1898); Savings \& Loan Soc'y v. McKoon, 120 Cal. 177, 52 Pac. 305 (1898); Byrne v. Hudson, 127 Cal. 254, '59 Pac. 597 (1899); Garwood v. Wheaton, 128 Cal. 399, 60 Pac. 961 (1900); Graves v. Arizona Cent. Bank, 205 Cal. 715, 272 Pac. 1063 (1928). See also Cat. Civ. Code $\$ 2889$.

00 See note 59 supra.

${ }^{61}$ See, e.g., Holibaugh v. Stokes, 192 Cal. App. 2d 564, 13 Cal. Rptr. 528 (1961); De Vrahnos v. George, 203 Cal. App. 2d 210, 21 Cal. Rptr. 481 (1962). These issues are, in fact, resolved by statute so that only the fact problems remain. Cax. Crv. CODE $\S \S 2925,2950$.

02 Even if the action is the debtor's bill to redeem, the decree must provide for a judicial sale upon the creditor's motion rather than for quieting the creditor's title in the event the debtor fails to pay. Compare Cline v. Robbins, 112 Cal. 581, 44 Pac. 1023 (1896) and Cowing v. Rogers, 34 Cal. 648 (1868) with Cohn v. Cohn, 1 Cal. 2d 313, 34 P.2d 1000 (1934). 
ment in Coast Bank to be an equitable mortgage. ${ }^{68}$ To be more precise, the question decided was stated by Justice Traynor to be the question that would have been presented had defendant-debtor denied that the parties intended to create a security interest and plaintiff-creditor offered extrinsic evidence to prove that they did. Since the extrinsic evidence would be admissible to interpret the instrument but not to give it a nieaning to which it was not reasonably susceptible, this is the same issue, reasonable susceptibility, that is presented when a party procedurally admits the intention to create a security interest as did the defendant-debtor in Coast Bank.

If one closely examines the opinion and considers it in view of the alternatives, it seems apparent that it comes out to mean that this form of agreement not to encumber property is either a nortgage or is a void contractual restraint on alienation at the election of the debtor. Inasmuch as the instrument seems to have been designed by a group of lenders to afford the lender the option of being a secured or unsecured creditor at the time of the debtor's default, placing the option instead with the borrower seems poetic justice. Moreover, it seems clearly correct on the merits.

- More often than not, this instrument will be held to have created a mortgage. But unlike the setting of Coast Bank, it will be the borrower, not the bank, that claims that it is a mortgage-otherwise it will not be. Consider the position of those banks that have chosen to rely upon this kind of ambiguity in an effort to obtain a later remedial advantage.

In the typical case where the borrower has given a promissory note for a snall loan and also has executed a Coast Bank-type agreement describing as its subject matter his heavily encumbered personal residence, the bank probably would prefer to recover after default by a simple action on the note to be satisfied out of the borrower's earnings, personal property, or, as a last resort, his encumbered residence. But any number of factors may impel the borrower toward choosing to treat the transaction as a secured loan. His obligations may be so heavy, for exanple, that he might conclude he would be better off simply to give up his real property in return for a discharge of the obligations representing the hens thereon, including, of course, the bank loan secured by the collateral agreement not to encumber. Possibly even for its nuisance value or, more charitably, in order to obtain the extension of time resulting from judicial foreclosure of a junior hien followed by the statutory year of redemption,

63 That the security interest was called an equitable mortgage would neither add to nor subtract from the remedies available; it is still a mortgage. Civil Code $\$ 2924$ provides: "Every transfer of an interest in property, other than in trust, made only as a security for the performance of another act, is to be deemed a mortgage. . .." 
the debtor may prefer treating his creditor as a secured creditor even though he ultimately intends to redeem his property. ${ }^{64}$ Regardless of his motivation, however, the borrower's defense is easy once he concludes, for any reason, that he wants the transaction to be treated as a secured transaction.

In response to the bank's action on the note, the debtor so inclined would defend by alleging that the indebtedness sued upon is secured, and therefore any suit other than foreclosure is barred by the one form of action provision of Civil Procedure section 726. ${ }^{65}$ His subsequent proof that the transaction is secured will be, in almost every case, overwhelmingly clear. To start with, the bank drew the agreement. The agreement describes specific real property and prevents the sale or encumbrance thereof until a certain indebtedness is paid. The indebtedness is subject to acceleration either upon default in payments on the concurrent promissory note or for breach of the agreement, through sale, additional encumbrance, or even failure to pay taxes on the specifically described property. The whole thing is recordable. Simply to describe it is to describe a mortgage. Except where the debtor claims that he did not so intend, the provisions of the document itself coupled with the statutory preference ${ }^{00}$ should be sufficient to establish that the agreement is a mortgage. Furthennore, the creditor would have difficulty in trying to explain what it is if not a mortgage.

As purely a contractual restraint on alienation it probably is void, ${ }^{07}$ but of greater importance from the standpoint of attempting to ascertain the intention of the creditor bank, it is, even if enforceable, a useless contract. The maximum damages the bank could suffer from breach would be the annount of the debt, the same amount for which it could get a judginent on the note. The contract benefits the bank only if it encumbers the property. It encumbers the property only if it is both subject to specific perfornance and subject to satisfaction by payment of the indebtedness, i.e., it encumbers the property only if it is a lien.

Once the debtor establishes that this is a secured transaction, he picks up all of the protections of a mortgagor. For example, notwithstanding

64 In the absence of a power of sale, the bank's foreclosure action would necessarily be followed by the full year statutory redemption period. See Cax. Code Crv. Proc. $\$ \S 702,725 \mathrm{a}$. The debtor may redeem from the sale any time during the year, and the likelihood is that the bank would keep the semior secured debt current to protect itself. The debtor could therefore redeem without paying a great deal all at once.

65 "There can be but one form of action for the recovery of any debt ... secured by mortgage upon real ... property ... " CaL. Code Crv. Proc. $\$ 726$.

66 See Civil Code $\$ 2924$.

67 See the cases cited in the opinion of the District Court of Appeal in 32 Cal. Rptr. at 584, including Prey v. Stanley, 110 Cal. 423, 42 Pac. 908 (1895); Wharton v. Mollinet, 103 Cal. App. 2d 710, 229 P.2d 861 (1951). 
the acceleration clause in the note the debtor may reinstate the loan without acceleration at any time prior to final judgment in the foreclosure action. ${ }^{68}$ And it will be a foreclosure action. The typical agreement does not contain a power of sale, and the bank, therefore, must utilize this "one form of action" as its sole remedy..69 At the resultant sale the bank is faced with somewhat of a dilemma. It may bid in the encumbered property in satisfaction of the small debt secured by its junior lien, thereby forcing itself to keep the senior encumbrances current to protect its newly acquired asset during the statutory year of redemption to which it is subject. Alternatively, if the bank chooses not to bid, it must prove the fair market value of the property by motion after the sale and risks being barred by the fair market value deficiency limitation. ${ }^{20}$ If the property in fact lias a fair market value greater than the amount of the bank's lien and the liens senior to it, the bank cannot obtain a deficiency judgment except to the extent the indebtedness exceeds this fair market value.

A foreclosure action followed by the fair market value determination is certamly an awkward and expensive way of collecting a small debt, but no worse probably than acquiring encumbered property and making an additional investment in it during the statutory year of redemption. How nuch better a simple action on the note would have been.

The obvious solution for the banks would be to terminate the outstanding agreements. But this, too, is not as simple as it sounds because the one form of action provision of section 726 is waivable only by the debtor, ${ }^{71}$ not by the creditor. ${ }^{72}$ And to compound the creditor's problem somewhat, in those cases where the banks either offer to terminate the agreement or, by pleading, clain to be unsecured creditors notwithstanding their having earlier recorded such an agreement, the debtor may choose not to defend on the basis of section 726 but instead to counterclain for slander of title. Indeed, if as the bank alleges the document does not encumber the real property but is instead simply an invalid contractual restraint on alienation, its recordation clouds the title with a false claim of an encumbrance so that the bank pleads itself into a clear case of disparagement. ${ }^{73}$

68 CaI. Civ. Code § 2924c.

69 Cal. Code Civ. Proc. \$ 726. See note 65 supra and accompanying text.

70 Code of Civil Procedure $\$ 726$ limits the deficiency to the difference between the fair market value at the time of sale and the amount of the judgment, a fact question to be proven by motion within 3 months of the sale.

71 See, e.g., Salter v. Ulrich, 22 Cal. 2d 263, 138 P.2d 7 (1943); Spector v. National Pictures Corp., 201 Cal. App. 2d 217, 20 Cal. Rptr. 307 (1962).

72 Roseleaf Corp. v. Chierighino, 59 Cal. 2d 35, 378 P.2d 97, 27 Cal. Rptr. 873 (1963).

73 See, e.g., Albertson v. Raboff, 46 Cal. 2d 375, 295 P.2d 405 (1956); Gudger v. Manton, 21 Cal. 2d 537, 134 P.2d 217 (1943); Fearon v. Fodera, 169 Cal. 370, 148 Pac. 200 (1915); Contra Costa County Title Co. v. Waloff, 184 Cal. App. 2d 59, 7 Cal. Rptr. 358 (1960). 
Coast Bank is an extremely important case. That the existence or the non-existence of the security depends upon the intention of the parties should be of little comfort to the creditor when it is evident that the only evidence adequate to cause this not to be security device will be the understanding and intention of the debtor. Where recorded, the agreement is either a lien or a slander of the debtor's title, debtor's choice. Undoubtedly, Justice Traynor's motive in writing the opimion in this way was to assure that institutional lenders would return to the unambiguous practices that are consistent with the integrity the public has the right to expect from this class of lenders. The quandry in which the lenders who have used Coast Bank-type documents now find themselves ${ }^{74}$ should tend to discourage further large scale experimentation with masked security devices. To the extent institutional lenders legally may, or wish to, engage in narrow margin, secondary secured financing, the bikelihood is they will do so, or will be prodded by the title insurance companies or the government into doing so, with security devices that say that they are security devices.

In the long run the hidden security aspect of Coast Bank probably will turn out to be a benefit to lenders in setting them straight before too many get too deeply involved. And in the short run, another part of this important opinion is immediately helpful to creditors. It establishes the validity of the call, or due-on-sale provision so often a part of a trust deed or mortgage.

The typical institutional trust deed will afford the lender the right to insist on full payment in the event of sale of the property by the trustor. When not used merely as a devise to obtain "prepayment" penalties, which probably are not collectible anyway when the "prepayment" is at the lender's option as it is upon exercise of the clause, ${ }^{75}$ the due-on-sale clause is a necessary protection for the lender. As is true with fire imsurers, the lender must be given a choice of borrowers to guard against the moral risks, here usually waste or poor credit which increase the bikelihood of having to retake the property. In the past, the validity of the clause was questionable because of the possibility of its being a restraint on alienation or of its being an acceleration subject to reinstatement under the Civil Code. ${ }^{78}$ Justice Traynor held it is not the former and implied it is not the Jatter. Both seem clearly correct.

Coast Bank's specific holding seemed a creditor victory-after all, the

74 The same fate is likely to await other misleading transactions. See, e.g., Golden State Lanes v. Foz, - A.C.A. - , 42 Cal. Rptr. 568 (1965). Cf. Shusett, Inc. v. Home Sav. \& Loan Ass'n, 231 A.C.A. 181, 41 Cal. Rptr. 622 (1964).

75 See generally Comment, 51 CaIT. L. REv. 923 (1963).

7 B CAL. CIv. CODE $\$ 2924 c$. 
bank won. Upon analysis though it becomes evident that what this particular bank won was protection for borrowers of the broadest kind. Yet ultimately, even this is likely to benefit the industry by forcing clarity, disclosure, and fairness upon all lenders. And that which was already a desirable creditor protection, the due-on-sale provision, was specifically approved. So overall, the case probably was what it seemed on its face, a creditor victory, even though it was also a significant debtor victory. It takes an extraordinarily skillful judge to write a majority opinion that can accomplish all of this in a few short pages. Chief Justice Traynor did so in Coast Bank, thus demonstrating again, as he had in his land contract and antideficiency opinions, that the extraordinary is the norm for this great jurist. 
. 